\title{
PREVALENCE OF UPPER DIGESTIVE ENDOSCOPY AND GASTRIC HISTOPATHOLOGY FINDINGS IN MORBIDLY OBESE PATIENTS
}

\author{
Judite DIETZ ${ }^{1}$, Jane Maria ULBRICH-KULCYNSKI², \\ Katia Elisabete Pires SOUTO ${ }^{3}$ and Nelson Guardiola MEINHARDT ${ }^{4}$
}

\begin{abstract}
Context - The prevalence of obesity has been increasing in modern society. Roux-en-y gastric bypass is a bariatric surgery that involves the exclusion of significant part of the stomach. Atrophy, intestinal metaplasia and gastric cancer have been associated with infection by Helicobacter pylori. Objectives - To evaluate the presence of endoscopy findings and histological changes in morbid obese patients for the presence of inflammatory cells, inflammatory activity, lymphoid hyperplasia, H. pylori infection, atrophy and intestinal metaplasia in the gastric mucosa. Methods - Upper digestive endoscopy and gastric histopathological were studied in 126 obese patients in the preoperative evaluation for bariatric surgery. Results - Upper digestive endoscopy abnormalities were diagnosed in 73/126 (57.9\%) patients. In three patients (2.4\%) the upper gastrointestinal endoscopy diagnosed gastric ulcer and one patient $(0.8 \%)$ had duodenal ulcer. The histopathological from gastric biopsies of these obese patients showed $65.1 \%$ of mucosa inflammation, inflammatory activity in $50.0 \%$, infection by $\mathrm{H}$. pylori in $53.2 \%$, lymphoid hyperplasia in $50.0 \%$ and atrophy and/ or intestinal metaplasia in $16.7 \%$. Conclusions - In present study, with routine preoperative upper gastrointestinal endoscopy and histopathological examination, were detected $57.9 \%$ patients with endoscopy abnormalities, high prevalence of infection by $H$. pylori $(53 \%)$ and $16.7 \%$ of gastric atrophy and/or intestinal metaplasia.
\end{abstract}

HEADINGS - Obesity, morbid. Gastric bypass. Endoscopy gastrointestinal. Helicobacter infections.

\section{INTRODUCTION}

Obesity is considered to be a growing problem in modern society and its prevalence has been increasing in both developed and developing countries ${ }^{(3)}$.

Most types of bariatric surgery include resection, sutures or partial stomach exclusion. The most frequent bariatric surgery is the Roux-en-Y gastric bypass (RYGBP), which involves partial exclusion of the stomach ${ }^{(3)}$.

Mucosal alterations after vertical banded RYGBP have not been clearly evaluated because the excluded stomach is not easily reached by conventional endoscopy ${ }^{(18,21,39)}$.

Infection by the Helicobacter pylori ( $H$. pylori) causes inflammation of the gastric mucosa, which can develop atrophy, intestinal metaplasia, dysplasia and cancer ${ }^{(3,6,27)}$. The eradication of the $H$. pylori leads to a regression of the inflammatory process of the gastric mucosa, the same does not happen in the more advanced stages, with the presence of atrophy and intestinal metaplasia ${ }^{(8,13,24,28,40)}$.
The present study aims to evaluate the prevalence of endoscopic findings and gastric histopathological alterations in morbidly obese patients. The histopathological alterations comprise presence of inflammation cells, inflammatory activity, presence of lymphoid hyperplasia, infection by the $H$. pylori, atrophy and intestinal metaplasia in the gastric mucosa.

\section{METHODS}

Consecutive study conducted in outpatient service with 126 morbidly obese patients [body mass index $\left.(B M I)=\geq 40 \mathrm{~kg} / \mathrm{m}^{2}\right]$ or obese patients (with BMI between $35-40 \mathrm{~kg} / \mathrm{m}^{2}$ ) with indication for bariatric surgery by significant co-morbidities. Upper gastrointestinal endoscopy (UGI) and gastric biopsies was required in the preoperative period. The patients had not undergone UGI or treatment to eradicate $H$. pylory previously. The study was approved by the Ethics Committee of Hospital Conceição, Porto Alegre, RS, Brazil, and all patients gave informed consent prior to their inclusion in the study. The upper endoscopies were realized by

Financial support: no. The authors declare that they have no conflicts of interest

Hospital Nossa Sra. da Conceição (HNSC), Class III Obesity Care Center, Porto Alegre, RS, Brazil.

${ }^{1}$ Division of Endoscopy, HNSC; ${ }^{2}$ Department of Pathology, Universidade Federal do Rio Grande do Sul (UFRGS); ${ }^{3}$ Division of Endocrinology, HNSC; ${ }^{4}$ Division of Bariatric Surgery, HNSC, Porto Alegre, RS, Brazil.

Correspondence: Dr. Judite Dietz - Rua Augusto L. Lima, 129 - ap. 701 - 90470-120 - Porto Alegre, RS, Brazil. E-mail: judi60@gmail.com 
the same gastroenterologist with a video-endoscope Fujinon series 400. Four gastric biopsies were carried out, two in the body and two in the antrum, always in the greater gastric curvature. Los Angeles and Sydney classification were used in the endoscopic analysis of esophagitis and gastritis ${ }^{(1,8)}$.

Alterations of the gastric mucosa were classified by the pathologist as an inflammatory process through the presence of lymphocytic and plasmocytic cells and inflammatory activity through the presence of neutrophils. Lymphoid hyperplasia, presence of $H$. pylori, epithelial atrophy and intestinal metaplasia were other parameters analyzed.

\section{RESULTS}

Female population predominated (104 patients - $82.5 \%$ ). The mean age was 42.08 years and the mean BMI was $51.2 \mathrm{~kg} / \mathrm{m}^{2}$ (standard deviation \pm 9.34 ).

Upper digestive diseases (UGI) were diagnosed in 73 patients $(57.9 \%)$ through endoscopy, being esophagitis and/or hiatal hernia in 31 cases $(24.6 \%)$; exsudative/enanthematous gastritis in 6 patients $(4.8 \%)$; exsudative/enanthematous erosive gastritis in 38 patients $(30.2 \%)$; gastric ulcer in $3(2.4 \%)$; duodenal ulcer in 1 obese $(0.8 \%)$. In $53(42.1 \%)$ patients the endoscopy was normal (Table 1). Some patients had more than one lesion at UGI.

TABLE 1. Upper digestive endoscopic findings $(n=126)$

\begin{tabular}{lcc}
\hline Diagnosis & Patients & Percentage \\
\hline Esophagitis and/or hiatal hernia & 31 & $24.6 \%$ \\
Exudative/enanthematous gastritis & 6 & $4.8 \%$ \\
Erosive gastritis & 38 & $30.2 \%$ \\
Gastric ulcer & 3 & $2.4 \%$ \\
Duodenal ulcer & 1 & $0.8 \%$ \\
Normal endoscopy & 53 & $42.1 \%$ \\
\hline
\end{tabular}

The prevalence of inflammatory cells in the gastric mucosa was found in $82(65.1 \%)$ patients, inflammatory activity in $63(50.0 \%)$, lymphoid hyperplasia in $63(50.0 \%)$, infection by H. pylori in $67(53.2 \%)$, epithelial atrophy and/or intestinal metaplasia in $21(16.7 \%)$ and normal gastric histopathological in $33(26.2 \%)$ patients (Table 2$)$.

TABLE 2. Histological analysis of gastric mucosa $(n=126)$

\begin{tabular}{lcc}
\hline Diagnosis & Patients & Percentage \\
\hline Mucosa inflammation & 82 & $65.1 \%$ \\
Inflammatory activity & 63 & $50.0 \%$ \\
Lymphoid hyperplasia & 63 & $50.0 \%$ \\
Helicobacter pylori & 67 & $53.2 \%$ \\
Epithelial atrophy and/or intestinal metaplasia & 21 & $16.7 \%$ \\
Normal & 33 & $26.2 \%$ \\
\hline
\end{tabular}

Five $(8.5 \%)$ of the 59 patients with negative results for $H$. pylori had gastric intestinal metaplasia or epithelial atrophy.

In these obese patients, the gastric histopathological parameters studied was not statistical different $(P<0.05 \%)$ in the patients with stomach or duodenum abnormalities at
UGI, comparatively with patients without any gastroduodenal abnormalities at UGI (Table 3), except the parameter inflammatory activity (Table 3 ). The diagnosis of inflammatory activity in gastric mucosa was greater in the group of normal UGI when compared with patients with UGI findings $(P=0.04)$ (Table 3).

\section{DISCUSSION}

The prevalence of obese individuals in USA (defined as BMI $>30 \mathrm{~kg} / \mathrm{m}^{2}$ ) has increased from $15.3 \%$ to $23.9 \%$ in the period of 1995 to 2005 and the prevalence of morbidly obese individuals (BMI $\left.>40 \mathrm{~kg} / \mathrm{m}^{2}\right)$ was of $4.8 \%$ in $2005^{(4)}$.

The most performed bariatric procedure is the RYGBP, which involves the exclusion of a significant part of the stomach. Lesions of the excluded stomach have been reported and the diagnosis of this possibility is difficult, onerous, not always available and, as a result of that, gastric diseases, such as ulcers and malignant neoplasms in the excluded stomach may not be diagnosed ${ }^{(18,21,39)}$.

H. pylori is associated to gastric diseases, such gastritis, ulcer, epithelial atrophy, intestinal metaplasia, lymphoma, adenocarcinoma ${ }^{(9,31)}$. The prevalence of infection caused by the $H$. pylori in Latin America is around 60\%, varying from $30 \%$ to $90 \%{ }^{(5)}$.

H. pylori causes inflammation of the gastric mucosa in all infected individuals ${ }^{(10)}$. This inflammation consists initially in recruitment of neutrophils, followed by lymphocytes, with later epithelial damage ${ }^{(15)}$. The chronic inflammatory process increases the turnover of epithelial cells and apoptosis (cellular death), evolving to epithelial atrophy and intestinal metaplasia ${ }^{(9)}$.

The development of gastric cancer involves several stages and can start with chronic gastritis, atrophy, intestinal metaplasia, dysplasia and finally invasive cancer ${ }^{(6)}$. The World Health Organization concluded, in 1994, for the existence of epidemiological and histological evidences to classify the $H$. pylori as carcinogenic, group $1^{(16)}$. Studies have shown the increased incidence of gastric cancer in the population infected by the $H$. pylori, as well as a positive correlation between intestinal metaplasia and stomach cancer ${ }^{(27,31,37)}$.

Eradication of the $H$. pylori leads to a regression of the inflammation, reduction of cellular turnover, increase in the acid secretion, which are important factors for the prevention of gastric cancer ${ }^{(9,14,22,24)}$. Some studies have concluded for the irreversibility of the carcinogenic process, even with the eradication of the $H$. pylori, basically when intestinal metaplasia of the stomach was present $t^{(13,14,20)}$.

The incidence of stomach cancer is still now a frequent causes in the group of world malignant neoplasm, being an important cause of mortality ${ }^{(17)}$. Few cases of gastric cancer in the bypassed stomach have been described after RYGBP for morbid obesity ${ }^{(18,36)}$. Factors such as difficulty of access to the excluded stomach and the reduced number of patients with adequate follow-up after bariatric surgery can interfere in this analysis.

The rationale for performing UGI in the candidates to bariatric surgery is to detect and treat lesions that might 
TABLE 3. Obese patients with endoscopic abnormalities in stomach and/or duodenum versus obese with normal stomach and/or duodenum at endoscopy. Gastric histopathological analysis

\begin{tabular}{|c|c|c|c|c|c|c|}
\hline & \multicolumn{2}{|c|}{$\begin{array}{l}\text { Abnormal stomach/duodenum } \\
\qquad(\mathrm{n}=46)\end{array}$} & \multicolumn{2}{|c|}{$\begin{array}{l}\text { Normal stomach/duodenum } \\
\qquad(\mathrm{n}=80)\end{array}$} & \multirow{2}{*}{$\begin{array}{l}\text { Odds ratio } \\
(95 \% \mathrm{CI})\end{array}$} & \multirow[t]{2}{*}{$P$-value } \\
\hline & $\mathrm{n}$ & $\%$ & $\mathrm{n}$ & $\%$ & & \\
\hline Mucosal inflammation & 48 & 60.0 & 34 & 73.9 & $0.52(0.23-1.17)$ & 0.08 \\
\hline Inflammatory activity & 35 & 43.8 & 28 & 60.9 & $0.50(0.23-1.04)$ & 0.04 \\
\hline Lymphoid hyperplasia & 40 & 50.0 & 23 & 50.0 & $1.00(0.48-2.06)$ & 0.57 \\
\hline Helicobacter pylori & 41 & 51.3 & 26 & 56.5 & $0.80(0.38-1.67)$ & 0.35 \\
\hline $\begin{array}{l}\text { Epithelial atrophy and/or } \\
\text { intestinal metaplasia }\end{array}$ & 15 & 18.8 & 6 & 13.0 & $1.53(0.55-4.28)$ & 0.28 \\
\hline Normal & 22 & 27.5 & 11 & 23.9 & $1.20(0.52-2.78)$ & 0.41 \\
\hline
\end{tabular}

$\mathrm{CI}=$ confidence interval

potentially lead to complications in the immediate postoperative period, or result in diseases in the months or years following RYGBP surgery ${ }^{(25,26)}$.

Eradication of the $H$. pylori as a routine in the preoperative of bariatric surgery is still debated and scarce researches were performed in regards the histology of gastric $\operatorname{mucosa}^{(2,7,11,23,25,26,30,33,34,35)}$.

Mong et al. ${ }^{(25)}$ studied 272 patients who were candidates to bariatric surgery, in which $33(12 \%)$ showed lesions in the upper digestive tract. Endoscopic findings were: esophagitis in 3.7\%; Barrett's esophagus in 3.7\%; gastric ulcer and/or erosive gastritis in $3.2 \%$; duodenal ulcer in $0.7 \%$ and gastric carcinoid tumor in $0.3 \%$.

Muñoz et al. ${ }^{(26)}$ diagnosed UGI abnormalities in $46 \%$ in the obese patients, one of them with gastric cancer.

Dutta et al. ${ }^{(11)}$ found prevalence of gastric ulcer of $2.9 \%$, identified histologically gastritis in $23.7 \%$ and $H$. pylori in $6.9 \%$ in the obese patients, finding that was not different from the control (non-obese) patients.

Safatle-Ribeiro et al. ${ }^{(33)}$ examined the excluded stomach in 40 patients by enteroscopy in an average of 78 months after surgery. In this study, an inflammatory process in the gastric mucosa was diagnosed in $100 \%$ of the cases, atrophy in $14 \%$, intestinal metaplasia in $11.4 \%$ and infection by the $H$. pylori in
$20 \%$. All cases of $H$. pylori infection in the excluded stomach also had the same infection in the gastric functional pouch.

A review of the literature revealed that the preoperative prevalence of $H$. pylori ranges from $6.9 \%$ to $61.3 \%$ in obese patients undergoing bariatric surgery $(2,11,12,19,23,29,30,32,38)$.

In the present study, there were $73(57.9 \%)$ cases with abnormalities in upper digestive endoscopy and 53 (42.1\%) patients with normal UGI. In 42 cases $(33.3 \%)$ gastroduodenal abnormalities were diagnosed, like exudative/ enanthematous gastritis, erosive gastritis, gastric or duodenal ulcers. Approximately $50 \%$ of the obese patients showed inflammatory activity and infection by the $H$. pylori and $16 \%$ had atrophy and/or intestinal metaplasia in gastric mucosa. The absence of $H$. pylori infection does not rule out gastric metaplasia or atrophy.

The prevalence of $H$. pylori infection and gastric atrophy and/or intestinal metaplasia in obese patients with gastric or duodenal lesions at endoscopy, comparatively with obese patients with normal stomach or duodenal at UGI, was not statistical different $(P<0.05)$.

The long-term follow-up of patients submitted to RYGBP may probably clarify if histopathological abnormalities of the gastric mucosa diagnosed prior surgery could interfere in the postoperative complications or in risk of gastric cancer.

Dietz J, Ulbrich-Kulcynski, Souto KEP, Meinhardt NG. Prevalência de achados gástricos endoscópicos e histopatológicos em pacientes obesos. Arq Gastroenterol. 2012;49(1):52-5.

RESUMO - Context - A prevalência de obesidade tem aumentado significativamente nos últimos anos. Bypass gástrico em Y-de-Roux, uma das técnicas cirúrgicas realizadas no tratamento da obesidade, envolve exclusão de parte do estômago. Atrofia, metaplasia intestinal e câncer gástrico têm sido associados com infecção pelo Helicobacter pylori. Objetivos - Avaliar a prevalência de achados endoscópicos e alterações histopatológicas em pacientes obesos mórbidos em relação à presença de células inflamatórias, atividade inflamatória, hiperplasia linfóide, infecção pelo H. pylori, atrofia e metaplasia intestinal na mucosa gástrica. Métodos - Achados na endoscopia digestiva alta e histopatologia gástrica foram analisados em 126 pacientes obesos na avaliação pré-operatória de cirurgia bariátrica. Resultados - Anormalidades endoscópicas do trato digestivo superior foram diagnosticadas em $73 / 126$ pacientes, com três pacientes $(2,4 \%)$ apresentando úlcera gástrica e um paciente $(0,8 \%)$ com úlcera duodenal. A histopatologia das biopsias gástricas dos obesos estudados revelou $65,1 \%$ de processo inflamatório na mucosa, atividade inflamatória em 50,0\%; infecção pelo $H$. pylori em $53,2 \%$, hiperplasia linfóide em 50,0\%, atrofia e/ou metaplasia intestinal em 16,7\%. Conclusões - No presente estudo, através de endoscopia digestiva alta e histopatologia de biopsias gástricas, foram detectados 57,9\% de pacientes com anormalidades endoscópicas, prevalência de infecção pelo $H$. pylori em $53 \%$ e atrofia e/ou metaplasia intestinal em $16,7 \%$.

DESCRITORES - Obesidade mórbida. Derivação gástrica. Endoscopia gastrointestinal. Infecções por helicobacter. 


\section{REFERENCES}

1. Armstrong D, Bennett JR, Blum AL, Dent J, De Dombal FT, Galmiche JP, Lundell L, Marguilies M, Richter JE, Spechler SJ, Tytgat GN, Wallin L. The endoscopic assessment of esophagitis: a progress report on observer agreement. Gastroenterology. 1996;111:85-92.

2. Azagury D, Domonceau JM, Morel P, Chassot G, Huber O. Preoperative workup in asymptomatic patients undergoing Roux-en-Y gastric bypass: is endoscopy mandatory? Obes Surg. 2006;16:1304-11.

3. Benotti PN, Forse RA. The role of gastric surgery in the multidisciplinary management of severe obesity. Am J Surg. 1995;169:361-7.

4. Centers for Disease Control and Prevention (CDC). State-specific prevalence of obesity among adults-United States, 2005. MMWR Morb Mortal Wkly Rep. 2006;55:985-8.

5. Coelho LG, León-Barúa R, Quigley EM. Latin-American Consensus Conference on Helicobacter pylori infection. Latin-American National Gastroenterological Societies affiliated with the Inter-American Association of Gastroenterology (AIGE). Am J Gastroenterol. 2000;95:2688-91.

6. Correa P. Human gastric carcinogenesis: a multistep and multifactorial processFirst American Cancer Society Award Lecture on Cancer Epidemiology and Prevention. Cancer Res. 1992;52:6735-40.

7. de Moura Almeida A, Cotrim HP, Santos AS, Bitencourt AG, Barbosa DB, Lobo AP, Rios A, Alves E. Preoperative upper gastrointestinal endoscopy in obese patients undergoing bariatric surgery: is it necessary? Surg Obes Relat Dis. 2008;4:144-9; discussion 150-1.

8. Dixon MF, Genta RM, Yardley JH, Correa P. Classification and grading of gastritis. The updated Sydney System. International Workshop on Histopathology of Gastritis, Houston 1994. Am J Surg Pathol. 1996;20:1161-81.

9. Dixon MF. Prospects for intervention in gastric carcinogenesis: reversibility of gastric atrophy and intestinal metaplasia. Gut. 2001;49:2-4.

10. Dooley CP, Cohen H, Fitzgibbons PL, Bauer M, Appleman MD, Perez-Perez GI, Blaser MJ. Prevalence of Helicobacter pylori infection and histologic gastritis in asymptomatic persons. N Engl J Med. 1989;321:1562-6.

11. Dutta SK, Arora M, Kireet A, Bashandy H, Gandsas A. Upper gastrointestinal symptoms and associated disorders in morbidly obese patients: a prospective study. Dig Dis Sci. 2009;54:1243-6.

12. Erim T, Cruz-Correa MR, Szomstein S, Velis E, Rosenthal R. Prevalence of Helicobacter pylori seropositivity among patients undergoing bariatric surgery: a preliminary study. World J Surg 2008;32:2021-5.

13. Fennerty MB. Gastric intestinal metaplasia on routine endoscopic biopsy. Gastroenteroly. 2003;125:586-90.

14. Gisbert JP, Blanco M, Pajares JM. [Effect of Helicobacter pylori eradication on histological lesions of gastric mucosa. An 18-month follow-up study]. Rev Clin Esp. 2000;200:480-4.

15. Goodwin CS, Armstrong JA, Marshall BJ. Campylobacter pyloridis, gastritis and peptic ulceration. J Clin Pathol. 1986;39:353-65.

16. IARC Working Group on the Evaluation of Carcinogenic Risks to Humans Schistosomoses, liver flukes and Helicobacter pylori. Lyon, France; 1994 (IARC monographs on the evaluation of carcinogenic risks to humans, v.61) 270p. Avaliable at: http://monographs.iarc.fr/ENG/Monographs/vol61/index.php

17. IARC Working Group International Agency for Research on Cancer. Lyon: International Agency for Research on Cancer. [Internet]. [cited July 11, 2007] Available at: http://www.iarc.fr.

18. Khitin L, Roses RE, Birkett DH. Cancer in the gastric remnant after gastric bypass: a case report. Curr Surg. 2003;60:521-3.

19. Lee WJ, Wang W, Lin CM, Chen TC, Wei PL. Seroprevalence of Helicobacter pylori in morbidly obese patients. Surg Obes Relat Dis 2005;1(3):258.

20. Leung WK, Lin SR, Ching JY, To KF, Ng EK, Chan FK, Lau JY, Sung JJ. Factor predicting progression of gastric intestinal metaplasia: results of a randomized trial on Helicobacter pylori eradication. Gut 2004;53:1244-9.

21. Lord RV, Edwards PD, Coleman MJ. Gastric cancer in the bypassed segment after operation for morbid obesity. Aust N Z J Surg. 1997;67:580-2.

22. Lu B, Chen MT, Fan YH, Liu Y, Meng LN. Effects of Helicobacter pylori eradication on atrophic gastritis and intestinal metaplasia: a 3-year follow-up study. World J Gastroenterol. 2005;11:6518-20.
23. Madan AK, Speck KE, Hiler ML. Routine preoperative upper endoscopy for laparoscopic gastric bypass: is it necessary? Am Surg. 2004;70:684-6.

24. Malfertheiner P, Sipponen P, Naumann M, Moayyedi P, Mégraud F, Xiao SD, Sugano K, Nyrén O, Lejondal H. pylori-Gastric Cancer Task Force. Helicobacter pylori eradication has the potential to prevent gastric cancer: a state-of-the-art critique. Am J Gastroenterol. 2005;100:2100-15.

25. Mong C, Van Dam J, Morton J, Gerson L, Curet M, Banerjee S. Preoperative endoscopic screening for laparoscopic Roux-en-Y gastric bypass has a low yield for anatomic findings. Obes Surg 2008;18:1067-73.

26. Muñoz R, Ibáñez L, Salinas J, Escalona A, Pérez G, Pimentel F, Guzmán S, Boza C. Importance of routine preoperative upper GI endoscopy: why all patients should be evaluated? Obes Surg. 2009;19:427-31.

27. Nomura A, Stemmermann GN, Chyou PH, Kato I, Perez-Perez GI, Blaser MJ. Helicobacter pylori infection and gastric carcinoma among Japanese Americans in Hawaii. N Engl J Med. 1991;325:1132-6.

28. Ohata H, Kitauchi S, Yoshimura N, Mugitani K, Iwane M, Nakamura H, Yoshikawa A, Yanaoka K, Arii K, Tamai H, Shimizu Y, Takeshita T, Mohara O, Ichinose M. Progression of chronic atrophic gastritis associated with Helicobacter pylori infection increases risk of gastric cancer. Int J Cancer. 2004;109:138-43.

29. O’Mahony R, Erim T, Szomstein S, Rosenthal R. Prevalence of Helicobacter pylori infection among patients undergoing bariatric surgery. Surg Obes Relat Dis. 2006;2(3):303

30. Papasavas PK, Gagné DJ, Donnelly PE, Salgado J, Urbandt JE, Burton KK, Caushaj PF. Prevalence of Helicobacter pylori infection and value of preoperative testing and treatment in patients undergoing laparoscopic Roux-en-Y gastric bypass. Surg Obes Relat Dis. 2008;4:383-8.

31. Parsonnet J, Friedman GD, Vandersteen DP, Chang Y, Volgeman JH, Orentreich N, Sibley RK. Helicobacter pylori infection and the risk of gastric carcinoma. N Engl J Med. 1991;325:1127-31.

32. Renshaw AA, Rabaza JR, Gonzalez AM, Verdeja JC. Helicobacter pylori infection in patients undergoing gastric bypass surgery for morbid obesity. Obes Surg. 2001;11:281-3.

33. Safatle-Ribeiro AV, Kuga R, Iriya K, Ribeiro U Jr, Faintuch J, Ishida RK, Corbett $\mathrm{CE}$, Garrido AB Jr, Ishioka S, Sakai P. What to expect in the excluded stomach mucosa after vertical banded Roux-en-Y gastric bypass for morbid obesity. J Gastrointest Surg. 2007;11:133-7.

34. Sauerland S, Angrisani L, Belachew M, Chevallier JM, Favretti F, Finer N, Fingerhut A, Garcia Caballero M, Guisado Macias JA, Mittermair R, Morino M, Msika S, Rubino F, Tacchino R, Weiner R, Neugebauer EA; European Association for Endoscopic Surgery. Obesity surgery: evidence-based guidelines of the European Association for Endoscopic Surgery (EAES). Surg Endosc. 2005; 19:200-21

35. Sharaf RN, Weinshel EH, Bini EJ, Rosenberg J, Sherman A, Ren CJ. Endoscopy plays an important preoperative role in bariatric surgery. Obes Surg. 2004; 14:1367-72.

36. Trincado MT, del Olmo JC, García Castaño J, Cuesta C, Blanco JI, Awad S, Carbajo MA. Gastric pouch carcinoma after gastric bypass for morbid obesity. Obes Surg. 2005; 15:1215-7.

37. Uemura N, Okamoto S, Yamamoto S, Matsumura N, Yamaguchi S, Yamakido M, Taniyama K, Sasaki N, Schlemper RJ. Helicobacter pylori infection and the development of gastric cancer. N Engl J Med. 2001;345:784-9.

38. Vanek VW, Catania M, Triveri K, Woodruff RW Jr. Retrospective review of the preoperative biliary and gastrointestinal evaluation for gastric bypass surgery Surg Obes Relat Dis. 2006;2:17-22; discussion 22-3.

39. Voellinger DC, Inabnet WB. Laparoscopic Roux-en-Y gastric bypass with remnant gastrectomy for focal intestinal metaplasia of the gastric antrum. Obes Surg. 2002;12:695-8.

40. Wong BC, Lam SK, Wong WM, Chen JS, Zheng TT, Feng RE, Lai KC, Hu WH, Yuen ST, Leung SY, Fong DY, Ho J, Ching CK, Chen JS, China Gastric Cancer Study Group. Helicobacter pylori eradication to prevent gastric cance in a high-risk region of China: a randomized controlled trial. JAMA 2004; 291:187-94. 